This item was submitted to Loughborough's Research Repository by the author.

Items in Figshare are protected by copyright, with all rights reserved, unless otherwise indicated.

\title{
Social identities from Leicester to Latin London
}

PLEASE CITE THE PUBLISHED VERSION

http://dx.doi.org/10.1080/13504630.2017.1314943

\section{PUBLISHER}

(c) Taylor \& Francis

\section{VERSION}

NA (Not Applicable or Unknown)

\section{PUBLISHER STATEMENT}

This work is made available according to the conditions of the Creative Commons Attribution-NonCommercialNoDerivatives 4.0 International (CC BY-NC-ND 4.0) licence. Full details of this licence are available at: https://creativecommons.org/licenses/by-nc-nd/4.0/

\section{LICENCE}

CC BY-NC-ND 4.0

\section{REPOSITORY RECORD}

Miller, Toby. 2019. "Social Identities from Leicester to Latin London". figshare.

https://hdl.handle.net/2134/25883. 


\section{SOCIAL IDENTITIES FROM LEICESTER TO LATIN LONDON}

\section{Toby Miller}

The Australian Political Studies Association rates Social Identities a 'B' journal. ResearchGate ranks our impact at 0.34 for 2015, down from an historic high of 0.66 in 2011. Excellence in Research for Australia gave us an 'A' in 2010. Scimago’s Journal \& Country Rank allocates the journal a score of 22 on the Hirsch Index. PreScopus Russia produced a 2013 Scientific Journal Ranking for us of 0.41. SciJournal doesn’t believe Social Identities exists. Journal-Data says we have no impact factor, and are closely related to Cardiovascular Therapy and Prevention (Russian Federation) and Forestry Studies in China (https://www.griffith.edu.au/business-government/griffithbusiness-school/pdf/journal-rankings-australian-politicalstudies-association.pdf;

https://www.researchgate.net/journal/13504630 Social Identities;

http://lamp.infosys.deakin.edu.au/era/?page=fordet10\&self or=1606;

http://www.scimagojr.com/journalsearch.php?q=12223\&ti p=sid; http://ores.su/en/journals/social-identities/; http://www.scijournal.org/search/search.php?query=social +identities\&search=1\&x=10\&y=10; http://www.journaldata.com/journal/social-identities.html)

MIGRATION HAS TRANSFORMED LEICESTER FROM A DULL PROVINCIAL MARKET TOWN INTO THE VIBRANT CAPITAL OF ASIA IN BRITAINJudith Vidal-Hall (2003)

El 85\% de los latinos con posibilidad de trabajar que viven en el Reino Unido desempeñan un empleo, aunque la mayoría realiza funciones laborales de limpieza y construcción con unos salarios mínimos. Además, el 40\% 
de los miembros de esta comunidad sufre discriminación en el trabajo por su raza, su carencia de buen inglés o su estatus legal

[85\% of Latin@s who live in Britain and are eligible to work do so. They are mostly in working-class occupations such as cleaning and construction, which pay very poorly. Forty per cent suffer discrimination on the job because of their race, command of English, or legal status]—Juanjo Andrés Cuervo (2014)

It's two decades since our journal started, and twelve years since Pal Ahluwalia and I took it over. Hence this set of commissioned essays by members of our editorial board. Following some preliminary remarks on Social Identities, and academic publishing more generally, this essay considers a frequently silenced and unseen social identityLatin Americans in Britain. The idea is to reflect on what the journal does and apply some of its tools.

\section{SOCIAL IDENTITIES}

I want to begin by stating my appreciation to the first editors for founding what became a thriving enterprise; to the publisher, for its support and efficiency; to our manuscript reviewers, for their voluntary labor; to our managing editors for their careful organizational work; to Board members who have contributed to this 
issue; and to Pal. We have had a fulfilling professional partnership and friendship in the years since 2004.

Our editorship began on the floor of his parents' home, looking askance at papers strewn across the carpet as we sought to organize a daunting array of all-too-material manuscripts, and less visible, but equally present, deadlines.

Since that time, the political economy and culture of academic publishing have changed dramatically. Countries with very centralized systems of higher education, such as Britain, Aotearoa/New Zealand, and Australia, have witnessed an intensified governmentalization and commodification of knowledge. Publicadministration notions of accountability have de-professionalized academics, diminishing intellectual freedom and mandating writing, research, and image tailored towards capital and state and published in the conventional journals of professional associations. Beyond the Anglosphere, many faculty are under new and intense pressure to work in English 
(http://www.cultureunbound.ep.liu.se/contents.asp?doi=10.3384/cu.2 000.1525.1574).

There has been massive inflation in the price of journal subscriptions (http://www.arl.org/storage/documents/expenditure-trends.pdf) and radical decreases in the proportion of college expenditure dedicated to libraries, which are dedicating more and more of their slender resources to purchasing proprietary data bases and journals rather than research monographs and edited collections (http://www.arl.org/storage/documents/eg_2.pdf).

The US Federal government is taking on big private-sector journal publishers in the sciences and medicine, whose massive profits are basically the product of corporate welfare-taxpayers fund most of the research, then pay for the libraries that buy it in published form (Holdren, 2013). That party is probably coming to a close.

And no one knows what the future of the book will be, as universities diminish their purchasing budgets. For-profit houses follow a strategy 
of producing books in high volume, given the cheapness of doing so, in the hope of occasional success. Many are of minimal quality. Publishers that give away digital copies of textbooks to students who have bought material ones find almost no one bothers with the virtual version. The promised cost reductions of a digital era have not arrived, as the labor of commissioning, evaluating, editing, and marketing continues to absorb as many resources as before (Miller, 2015).

Journals such as ours continue to proliferate as solid sources of cash flow, but no one knows for how long, given US policies and the flawed ranking systems favored by schools and governments and indexed in the first epigraph above. Critical bibliometricians refer to a 'metric tide' that is being generated by a state auditing fetish, the fashion for big data, an all-consuming desire to manage scholarship, and artificially-created competition within and between universities (Independent Review, 2015). 
The Journal Impact Factor, now so often taken as holy writ/indubitable science, was originally designed to assist librarians in their purchasing decisions. The 570 organizations and 12,300 individuals who have signed the San Francisco Declaration on Research Assessment (DORA), sponsored by the American Society for Cell Biology, point out that the system skews the distribution of citations, treats different genres of writing as identical, and is both open to manipulation by editorial policy and closed to external scrutiny. DORA proposes eliminating such metrics from faculty hiring decisions, and focusing on the quality of research and writing rather than the outlets where they appear (http://www.ascb.org/dora/).

We trust that Social Identities is a bit more interesting than its impact scores—or lack of them—and that it resists disciplining, diminishing, marketing, and maundering. And we hope, most of all, that it embodies a dynamic academic diversity. That last word brings me to the principal substance of this paper, which has been animated by the mixture of textual analysis, political economy, and ethnography that characterizes our journal. 


\section{DIVERSITY}

Much of British multiculturalism has rightly been dedicated to migrants and their families who moved there, at least in part, as a consequence of histories of conquest, enslavement, and colonization, as encapsulated in the rallying cry, 'We are here because you were there.'

The UK has not even begun the necessary task of paying reparations to descendants of the people whose homes and lives it besieged, occupied, and seized. But there is a (very incomplete) project of redefining national identity in the light of this latter-day immigration to the metropole from former colonies and others.

Take Leicester, a light-industrial market town in England's East Midlands that lost its manufacturing base in textiles, clothing, and footwear and its entrepôt role for coal in the 1960s, which was also an era of grotesque redevelopment and mad road-building. The city's history was, however, distinctive in that it had favored the 
revolutionary side in the 17th-century Civil War, and boasted a tradition of religious pluralism (Popham, 2013).

In 1972, South Asians faced sudden expulsion from East Africa.

Many were British citizens. The burghers of Leicester addressed them via a notorious advertisement in the Uganda Argus: 'PRESENT CONDITIONS IN THE CITY ARE VERY DIFFERENT FROM THOSE MET BY EARLIER SETTLERS.’ They warned of limited social welfare and dire employment prospects (quoted in Popham, 2013).

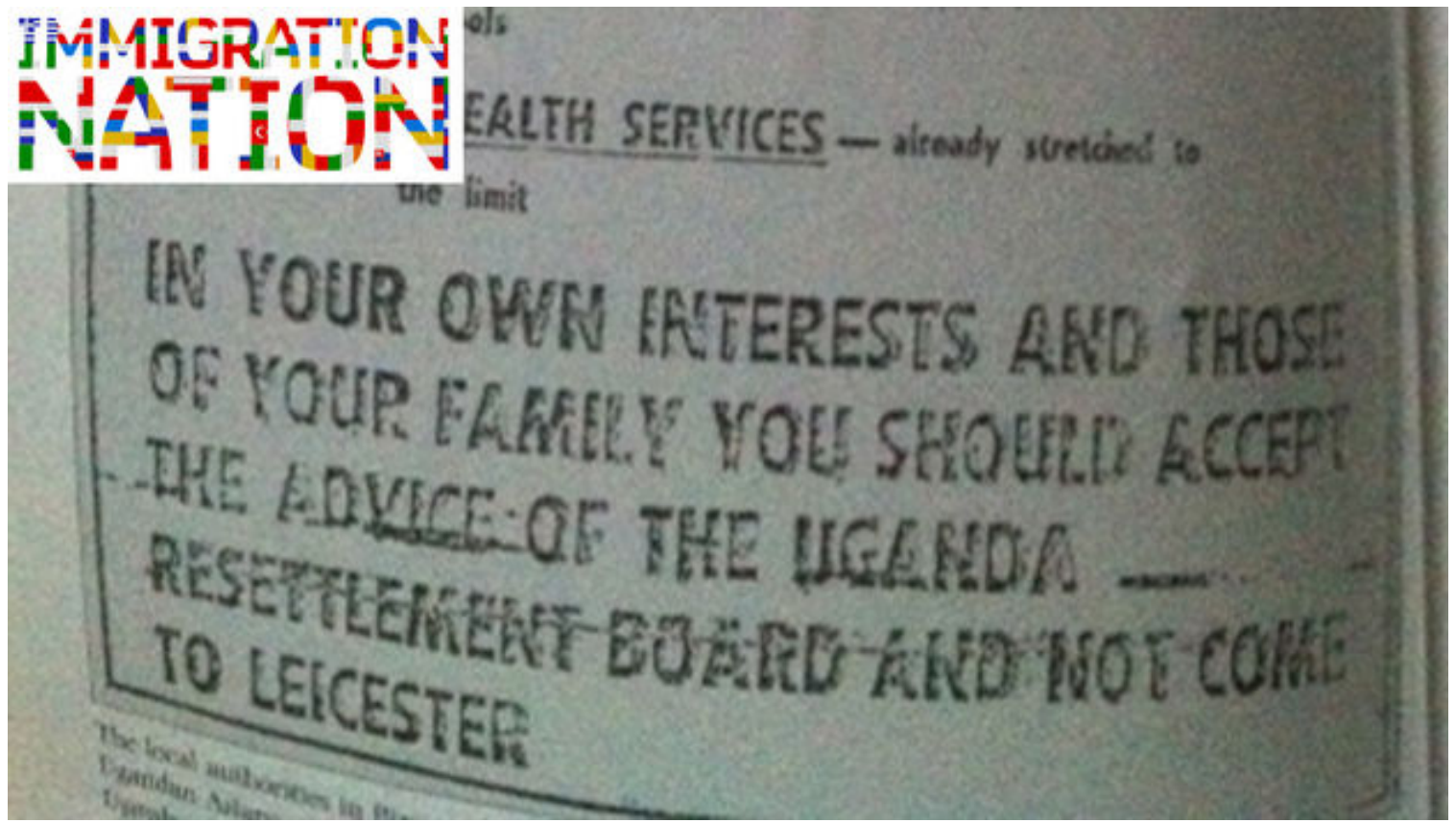

(http://www.channel4.com/news/immigration-leicester-ugandanasians-darshna-soni) 
But that admonition, and related news stories promoting the city's desire to avoid Asian immigration, had the paradoxical effect of attracting it, putting Leicester on the map for liberal professionals and businesspeople. They were ready to purchase and refit the factories, offices, and yards that white capital was abandoning, and to do so without committing to politicized religion, confident in the utility of educational and cultural capital (Marett, 1993; Vertovec, 1994; Robinson, 1993; Vidal-Hall, 2003; Ivanescu 2016: 105-31).

The city's demography was soon transformed, not least as their arrival coincided with Britain's admission to what is now the European Union, thereby dealing a further blow to the country’s provincial racism and monolingualism. There were years of reactionary racist violence in the 1970s, but local government supported ultimately successful multicultural civil-society organizations. Leicester is now officially proud to be a majority-minority city (http://www.visitleicester.info/things-to-see-and-do/festivalscelebrations/an-indian-summer/). 
Seventy languages are spoken, across a population of under 350,000.

There are Jain and Buddhist centers, two synagogues, over a dozen Hindu temples, several Sikh gurdwaras, more than seventy mosques, an extraordinarily diverse cuisine — and a champion football team owned by Thai oligarchs (Vidal-Hall, 2003; Popham, 2013; http://mosques.muslimsinbritain.org/maps.php\#/town/Leicester; http://crossculturalcuisine.omeka.net/;

http://www.publicspirit.org.uk/assets/LeicesterDiversityOfLeicester.p df; http://www.kingpoweronline.com/en; Miller, 2016).

Many taxi drivers are learning French, because wealthy teenage Chinese daughters of cadre, in Leicester for college, casually hail them on the street asking to go to the south of France (it's a mere $1544 \mathrm{~km}$ to Cannes). And East Midlands airport boasts weekly flights to México (http://www.eastmidlandsairport.com/destinations-andguides/cancun/). From commerce to local government, diversity is a norm, and an informal economy operates neatly alongside conventional exchange in a mixture of state capitalism and mutual aid (Hall et al., 2016). 
So far, so good. But away from this organic commercial and religious pluralism—not of mere integration, but of urban redefinition-the UK's wider critiques, policies, and practices of multiculturalism have failed to keep pace with migration to Britain from beyond its abandoned empire and subsequent Commonwealth.

Polish is now the third language in the land after English and Welsh, ${ }^{1}$ and the proliferation of Spanish and Portuguese is well ahead of Bengali and Gujarati and just below Punjabi and Urdu (http://www.ons.gov.uk/peoplepopulationandcommunity/populationa ndmigration/populationestimates/bulletins/2011censusquickstatisticsf orenglandandwales/2013-01-30\#tab-Main-language).

But you'd never know the importance of Polish, Spanish, and Portuguese language groups from media, governmental, academic, and activist discussions of diversity, which are principally conducted in racialized and religious terms that derive from the nation's colonial past. Debates about inclusiveness in the BBC, the arts, and 
publishing, for instance, have utterly failed to think of Poles as ignored members of society. Why? They don't fit a model that is inexorably tied to the imperial binaries—of supremacy and lamentation, pride and guilt, presence and loss — that animate British people across classes. One consequence: the anti-Polish xenophobia exhibited by the white working class in Wales and northern England that propelled the referendum vote to leave the EU in 2016 (Leicester voted to remain, needless to say). Poles were deemed to have undermined proletarian jobs, and failed to integrate. But which governmental and cultural institutions addressed them, citizens of the country’s oldest ally? A similar social-movement, scholarly, and policy neglect applies to the group I'll focus on in the rest of this paper.

\section{LATIN@S IN BRITAIN}

Latin Americans came to the UK as political exiles in the $18^{\text {th }}$ century during the continents’ numerous nationalist struggles contra Spain. Politicians and intellectuals alike, such as Francisco de Miranda, Simón Bolívar, Bernardo O’Higgins, and José de San Martín, arrived 
in search of safety, money, and influence. Several were active in

London’s mysterious Gran Reunión Americana, which advocated for independence (“A Brief,” n. d.;

http://lautaro.org.ve/biblioteca/trazados/2010-2014/2013-2/la-gran-

reunion-americana-miranda-ohiggins-y-las-logias-lautarinas/).

The British economy imposed itself on a newly-independent Latin America across the $19^{\text {th }}$ century, via banking, manufacturing, shipping, and football rather than imperial possession. That commercial influence ground to a halt in the 1930s with the Great Depression, unlike the settlement, enslavement, and rule experienced in Asia and Africa. As such, the contemporary notion of a responsibility to peoples who were occupied or bought and sold, from Africa to South Asia to the Arab world, barely applies to Latin@s, even though the UK's influence on the region's incorporation into world capitalism was profound (Posada Carbó, 1993).

In the 1970s, a second wave of immigration to Britain from the region saw people seeking asylum. It is a striking, graphic experience to 
confront the map of the world in Santiago’s Museo de la Memoria and confront the fact that the UK government admitted no Chilean refugees from the fascists in 1973. That number again: zero. As always, the Conservative Party incarnates the best of Britishness. Tally ho! Watch out for Johnny Foreigner! ${ }^{2}$

250,000 Latin Americans are now estimated to be living in the UK, of whom 145,000 reside in the capital. They are comprised of 'regular, irregular and second generation groups, comparable in size to other large migrant and ethnic groups such as the Polish population,' with 'a nearly fourfold growth in Latin Americans in London since 2001' (McIlwaine et al. 2013: 7). Their principal countries of origin are Brazil (a recent source of migrants, it provides the plurality), Colombia (the most-established point of origin), Argentina, México, Ecuador, Venezuela, Perú, Chile, Bolivia, and Cuba. They are more numerous than immigrant populations from west Africa, Bangladesh, Somalia, China, Romania, and Pakistan, and the fastest-growing nonEU group after the Chinese (McIlwaine and Bunge, 2016). 
There are few Latin@ children or elderly people, about a third cannot speak English, and roughly a fifth are sin papeles, or without legal status. A quarter are British citizens and a fifth have EU passports, often via Spain —-many left there because of the UK's stronger recovery from the Great Recession (McIlwaine et al., 2013; Cuervo, 2014).

At 85\%, Latin Americans' employment rate is the highest of any ethnic group in London, including the majority Anglo-Celts. Many labor in the precarious service or construction sectors in two or three effectively part-time jobs, each of which provides less than the London Living Wage. Although 70\% have post-secondary education, their move to Britain usually produces downward mobility in status from their places of origin (94\% say their class position has deteriorated since arriving). Student migrants and temporary residents expect to consolidate their residency status and enter the professionalmanagerial sphere (McIlwaine et al., 2013;

http://www.trustforlondon.org.uk/policy-change/strategic-workitem/london-living-wage/). 
Latin Americans face special issues of exclusion from Britain's official, social-movement, scholarly, cultural, and communications discourses on diversity. Why? The discourse of social identities in the Anglosphere is frequently characterized by hangovers from the white supremacism expressed and engendered by imperial and colonial rule and their legacies. These racial codings are as scarred by ignorance as bias, so Latin America is largely invisible and inaudible in Britain, apart from press coverage of footballers in the English Premier League and white leftists' delusions about Chavismo, Sandinismo, Zapatismo, Fidelismo, or whatever is their latest angloparlante/instant-activist fetish. On the Heathrow Express from central London to the airport, world weather adorns various TV screens. Detailed forecasts are available for Africa, Europe, Oceania, the US, Canada, and Asia. Latin America? Not so much, despite the fact there are, for instance, daily flights to Bogotá, Rio de Janeiro, Buenos Aires, and São Paulo. 
Three-quarters of Latin@s in Britain complain of discrimination from employers, everyday people, and public services. They experience an alienating marginality and note in particular inadequate provision of affordable English classes. In terms of diversity and identification, $40 \%$ adhere to the Latin American ideology of mestizaje (the idea of being mixed race). The remainder call themselves either 'white (other),' in the Census, or Latin American. ${ }^{3}$ Some answer to 'British Latino' or 'the Invisibles,' and many cohere around the slogan “London Without Latins Would Be Filthy” (Muir, 2012; McIlwaine et al., 2013; Milmo, 2013).

The Latin American advocacy groups that emerged in Britain’s third sector during the 1980s spoke out about human rights violations in dictatorships back home. They were hoping for popular solidarity from the public and diplomatic pressure from the state. There has been a transformation in their mission since then, from intervening in international politics to offering collective self-help. It’s homologous to the change in reasons for people arriving, from the sudden flight of the refugee to the coach seat of the economic migrant. 
The former Chile Democrático is now the Indoamerican Refugee and Migrant Organisation (http://irmo.org.uk/). The Coalition of Latin Americans in the UK offers social and economic tips, assistance, and contacts, plus links to media stories (https://www.facebook.com/CLAUKLondon/). LatinElephant provides a counter-discourse to the dominant message of London developers, who wish to transform parts of London such as Seven Sisters and Elephant \& Castle that have been hives of Latin American business (https://latinelephant.wordpress.com/). The Latin American Women’s Rights Service is:

a user-led, feminist and human rights organisation that has been working with Latin American women in the UK since 1983. Our aim is to facilitate the tools for Latin American women to assert our human rights and pursue personal empowerment and social change. We are a holistic organisation and provide culturally and linguistic specialist advice, information, counselling and psychotherapy, advocacy, development programmes, workshops, wellbeing groups and targeted support to Latin American women (http://www.lawrs.org.uk/en/)

The shift in focus from political issues at home to success abroad signifies not only the democratization of Latin America over the past 
thirty years, but also the travails of increased migration to the UKdriven by economic hope, yet dogged by inequality, poverty, and exclusion.

The concept of diversity is meaningless without official recognition of difference (García Canclini, 2002). 77\% of today’s residents seek inclusion alongside other minorities in the formation and implementation of British public policy and everyday life. But official minoritization is hard to obtain absent the responsibility/guilt/moral suasion forced onto a liberal-democratic society whose colonial history of enslavement and dispossession directly stimulated so much immigration, so just a few local councils accord Latin@s minority status (McIlwaine et al., 2013).

Colonial quasi-reparations or guilt-induced quotas/targets (Curtis and Patrick, 2014) are irrelevant in their case. Latin Americans need the kind of policies supporting an authentic diversity of which Idris Elba has spoken:

Diversity in the modern world is more than just skin 
colour. It's gender, age, disability, sexual orientation, social background, and-most important of all, as far as I'm concerned-diversity of thought (quoted in Martinson, 2016)

Policies for diversity in truly inclusive, democratic societies must acknowledge and compensate for the disgraceful heritage of empire. But they must equally engage today's real material demography, or working people will again be shunted aside from the nation's dominant daily narrative and attendant social services. As the triumph of xenophobia and regressive post-imperialism known as Brexit marches on, with repeated abuse of Poles and Muslims its latest totems, Latin@s too are suffering, afraid that their right to live in Britain and feel socially accepted are in jeopardy as a comparatively plural and inclusive society gives way to a closed, monocultural nationalism (Chipana Gutiérrez, 2016).

\section{CONCLUSION}

Social Identities' two decades of alternatively dynamic and routine, chaotic and ordered existence have seen a wide variety of arguments and debates in the name of scholarship and socio-cultural justice. As I 
think about this period, I am drawn back to a moment just before the journal began. Emerging from the terrible suffering of racial-state brutality and public violence, Rodney King famously asked ‘Can’t we all get along?' (https://www.youtube.com/watch?v=1sONfxPCTU0).

The idea of tolerance has long been decried by the left, derided as a form of repression that refuses a full-throated role for all in determining the politics of national life by urging us instead to 'get along' and not be too loud or demanding.

At a moment when the US general election has been won by the angriest, loudest, least decorous candidate on record, the kind of tolerance that Leicester's Asians achieved and King called for, and the desire for inclusion that UK Latin@s seek, seems not too repressive. And tub-thumping expressivity seems none too loveable.

\section{WORKS CITED}

"A Brief History of Latin Americans in London.” (n. d.). Latino Life http://www.latinolife.co.uk/node/167. 
Chipana Gutiérrez, Claudio. (2016, October 6). “Brexit, cohesión social y reconocimiento de la comunidad Latina.” ThePrisma http://theprisma.co.uk/es/2016/10/06/brexit-cohesion-social-yreconocimiento-de-la-comunidad-latina/.

Cuervo, Juanjo Andrés. (2014, August 23). “La realidad del desempleo y la inmigración en Gran Bretaña.” ThePrisma http://theprisma.co.uk/es/2014/08/23/la-realidad-del-desempleo-yla-inmigracion-en-gran-bretana/.

Curtis, Barry and Ellen Patrick. (2014). "Implicated: A Review Paper on Guilt.” Economy and Society 43, no. 1: 136-52.

García Canclini, Néstor. (2002). Latinoamericanos buscando lugar en este siglo. Buenos Aires: Paidós.

Hall, Suzanne, Julia King, and Robin Finlay. (2016). “Migrant Infrastructure: Transaction Economies in Birmingham and Leicester, UK.” Urban Studies doi:10.1177/0042098016634.

Holdren, John P. (2013, February 22). "Memorandum for the Heads of Executive Departments and Agencies.” Executive Office of the President, Office of Science and Technology Policy https://www.whitehouse.gov/sites/default/files/microsites/ostp/ostp _public_access_memo_2013.pdf.

Independent Review of the Role of Metrics in Research Assessment and Management. (2015). The Metric Tide Higher Education Funding Council for England http://www.hefce.ac.uk/pubs/rereports/Year/2015/metrictide/Title, 104463,en.html.

Ivanescu, Carolina. (2016). Islam and Secular Citizenship in the Netherlands, United Kingdom, and France. Houndmills: Palgrave Macmillan.

McIlwaine, Cathy, Juan Camilo Cock, and Brian Linneker. (2013).

No Longer Invisible: The Latin American Community in London. Queen Mary, University of London; Latin American Women's Rights Service; Trust for London http://www.geog.qmul.ac.uk/docs/research/latinamerican/48637.pd f.

McIlwaine, Cathy and Diego Bunge. (2016). Towards Visibility: The Latin American Community in London. Trust for London 
https://www.trustforlondon.org.uk/wpcontent/uploads/2016/07/Towards-Visibility-full-report.pdf.

Marett, Valerie. (1993). "Resettlement of Ugandan Asians in

Leicester.” Journal of Refugee Studies 6, no. 3: 248-59.

Martinson, Jane. (2016, January 24). "Diversity on Television is Not

Just a Black and White Issue.” Guardian

http://www.theguardian.com/media/2016/jan/24/diversity-racegender-media-television.

Miller, Toby. (2015). "Humanities Top to Bottom: The Cognitariat and Publishing." Ctrl-Z: New Media Philosophy 5 http://www.ctrlz.net.au/journal/?slug=miller-humanities-bottom-to-top.

Miller, Toby. (2016). "Leicester City Cinderella Story Authored by Thai Oligarch.” Asia Sentinel 18 May http://www.asiasentinel.com/econ-business/leicester-city-littleclub-oligarch/\#frameId=appnext_widget\&height=84. Milmo, Cahal. (2013, July 20). “UK’s 200,000-Strong South American Community ‘Needs Ethnic Recognition'.” Independent http://www.independent.co.uk/news/uk/politics/uk-s-200000strong-south-american-community-needs-ethnic-recognition8723047.html.

Muir, Hugh. (2012, March 4). "Hideously Diverse Britain: The UK’s Latin American Community is Fighting for Recognition."

Guardian http://www.theguardian.com/uk/2012/mar/04/uk-latinamerican-community.

Popham, Peter. (2013, July 27). "We're All in This Together: How Leicester Became a Model of Multiculturalism (Even if That was Never the Plan ...).” Independent

http://www.independent.co.uk/news/uk/this-britain/were-all-inthis-together-how-leicester-became-a-model-of-multiculturalismeven-if-that-was-never-8732691.html.

Posada Carbó, Eduardo. (1993). “América Latina en la Gran

Bretaña.” Revista de Estudios Internacionales 26, no. 104: 681701.

Robinson, Vaughan. (1993). "Marching into the Middle Classes? The Long-Term Resettlement of East African Asians in the UK." Journal of Refugee Studies 6, no. 3: 230-47. 
Vertovec, Steven. (1994). "Multicultural, Multi-Asian, Multi-Muslim Leicester: Dimensions of Social Complexity, Ethnic Organization and Local Government Interface.” Innovation: The European Journal of Social Science Research 7, no. 3: 259-76.

Vidal-Hall, Judith. (2003). "Leicester: City of Migration.” Index on Censorship 32, no. 2: 132-41.

${ }^{1}$ See volumes 22, no. 1 of the journal for 2016 and 16, no. 3 for 2010, which focus on Polish people across Europe.

2 The debate in the House of Lords on the callousness of the British Embassy is particularly telling (http://hansard.millbanksystems.com/lords/1973/dec/04/chile-britishembassy-and-refugees).

${ }^{3}$ While it includes helpful information, the UK Census is testimony to the nation's imperial obsessions in its demographic research (http://www.ons.gov.uk/peoplepopulationandcommunity/culturalident ity/ethnicity/articles/ethnicityandnationalidentityinenglandandwales/2 012-12-11). Latin Americans are barely represented. 